\title{
PERTUMBUHAN EKONOMI PASAR MODAL SYARIAH \\ DI MASA PANDEMI COVID 19
}

\author{
GUSTI YUSMIANA \\ Jurusan Perbankan Syariah, Fakultas Ekonomi dan Bisnis Islam, \\ Universitas Islam Negeri Alauddin Makassar \\ Email : yanyan10025072@gmail.com
}

\begin{abstract}
ABSTRAK
Perekonomian global termasuk Indonesia mengalami kondisi yang tidak stabil. Dampak pandemi Covid 19 ini sangat berpengaruh terhadap segala aspek terutama pada kondisi Perekonomian masyarakat. Dengan bertambahnya kasus positif Covid 19 di Indonesia membawa efek bagi pasar modal syariah yang masih tertekan di tengah perjuangan Indonesia melawan virus Covid -19. Pasar modal Syariah diperkirakan tidak akan menerima dampak secara langsung dari penyebaran covid-19 dikarenakan pasar modal syariah memiliki seleksi terhadap rasio keuangan suatu emiten dan saham syariah tetap bisa bertahan walaupun ekonomi sedang anjlok dikarenakan saham syariah memiliki kekuatan transaksi sehingga tetap stabil dan instrumen syariah. Pertumbuhan yang sangat pesat ini, dilihat dari perkembangan produk pasar modal syariah seperti saham syariah, sukuk, dan reksadana syariah yang mengalami pertumbuhan setiap tahun. Sehingga pertumbuhan tentunya berpengaruh terhadap perkembangan pasar modal dan juga akan berpengaruh terhadap perekonomian di Indonesia. Dengan adanya Covid 19 ini sehingga semua kegiatan di pasar modal syariah berubah dari ketentuan seperti dalam perubahan jam perdagangan
\end{abstract}


di Bursa Efek, adanya perubahan sistem auto rejection ( batas minimum) serta terjadinya kemerostan IHSG.

Kata kunci: Syariah, Modal, Pasar, Ekonomi, Covid 19.

\section{A. PENDAHULUAN}

Indonesia merupakan salah satu negara berkembang yang membutuhkan banyak modal untuk meningkatkan pembangunan perekonomiannya yaitu dengan menumbuhkan sektor investasi dengan instrumen pasar modal. Pasar modal syariah juga memberikan kesempatan bagi umat muslim dan juga yang non muslim yang ingin menginvestasikan dananya sesuai dengan prinsip atau aturan syariah yang dapat memberikan keyakinan atas transaksi yang halal dari investasinya.

Pandemi covid -19 yang terjadi saat ini berimbas pada kehidupan manusia dalam bidang ekonomi, pandemi ini tidak hanya terjadi masalah di sektor riil saja, namun berimbas juga pada sektor keuangan. Sehingga perekonomian di Indonesia mengalami penurunan dan mengarah pada resesi ekonomi dikarena pandemi covid 19 ini. Perlambatan ekonomi pasti akan berdampak pada kinerja pertumbuhan ekonomi di Indonesia, salah satunya yaitu pertumbuhan pasar modal syariah. Dengan 
bertambahnya kasus positif covid 19 di Indonesia yang memberikan efek bagi pasar modal syariah.

Pasar modal syariah ini merupakan media investasi bagi umat Islam sehingga lebih mengutamakan dalam prinsip- prinsip Islam. Pasar modal syariah memiliki ciri khas tersendiri seperti harga yang diberikan masih minimum, informasi yang di berikan akurat, jauh dari perilaku riba, gharar, serta perjudian atau transaksi yang dapat melanggar aturan syariah.

Dewan Syariah Nasional Majelis Ulama Indonesia (DSN-MUI) untuk pertama kali mengeluarkan fatwa yang berkaitan langsung dengan pasar modal, pada tanggal 18 April 2001 yaitu Fatwa Nomor 20/DSN-MUI/IV/2001 tentang Pedoman Pelaksanan Investasi Untuk Reksa Dana Syariah. dan pada awal bulan September 2002 selanjutnya, instrumen investasi syariah di pasar modal terus bertambah dengan kehadiran Obligasi Syariah. Instrumen ini merupakan Obligasi Syariah yang pertama dengan akad yang digunakan yaitu akad mudharabah. 


\section{B. PEMBAHASAN}

1. Dampak Pandemi Covid 19.

Awal tahun 2020 dunia mengalami kehebohan dengan adanya kasus covid 19 yang berasal dari Wuhan (China) ini. Adanya virus ini menyebabkan kepanikan bukan hanya kepanikan di Wuhan melainkan di dunia sebab wabah covid ini menyebar hampir di setiap negara. Sehingga banyak perusahaan kecil, menengah maupun yang besar yang menutup usahanya untuk sementara. Tidak hanya perusahaan saja yang tutup, tetapi ribuan tempat usaha makanan dan minuman, dan taman wisata pun juga terpaksa tutup. Tidak hanya waspada terhadap penyebaran virusnya saja akan tetapi juga waspada terhadap dampak dampak yang mungkin akan terjadi terhadap perekonomian dunia baik jangka panjang dan jangka pendek seperti halnya dalam dampak perlambatan ekonomi global. Semakin banyak orang orang yang terinfeksi maka semakin banyak pengeluaran biaya dalam perawatan dan juga biaya produksi lainya yang akan ditanggung oleh negara sendiri.

Dampak Covid 19 sangat berdampak dalam kegiatan 
perekonomian di Indonesia, dimana didalamnya ada kegiatan berinvestasi, ada beberapa sektor diantaranya adalah pengaruh pada pasar saham, surat utang dan nilai emas, juga pada perdangangan karena masih megandalkan kegiatan ekspor-impor dari Cina. (Abdi, 2020)

Salah satu landasan dalam berinvestasi yaitu surah QS. Yusuf ayat 47 yang berbunyi :

$$
\begin{aligned}
& \text { حَصَدْتُمْ فَهَا دَأَبًا سِنِينَ سَبْعَ تَزْرَعُونَ قُالَ }
\end{aligned}
$$

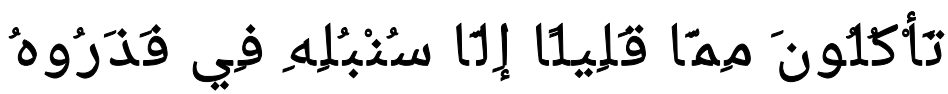

Artinya : "Supaya kamu bertanam tujuh tahun (lamanya) sebagaimana biasa, maka apa yang kamu tuai hendaklah kamu biarkan dibulirnya kecuali sedikit untuk kamu makan”.

Dalam menjalankan kegiatan pasar modal syariah ini tetap menetapkan prinsip-prinsip syariah agar pihak-pihak yang melakukan kegiatan tersebut mendapatkan ridho dan berkah di sisi Allah swt. Dan para pihak pihak yang terkait dalam pasar modal juga harus mempunyai persiapan jika terjadi 
sesuatu pada negara seperti pandemi saat ini agar dapat meminimalisir keuntungan atau kerugian yang terjadi sehingga pada pasar modal syariah tidak mengalami penurunan yang sangat drastis.

2. Pertumbuhan Pasar Modal Syariah

Pasar modal syariah ini sangat berpengaruh terhadap pertumbuhan ekonomi nasional, dengan mendorong laju pertumbuhan ekonomi di Indonesia dilihat dari perkembangan pasar modal syariah akan berpengaruh seperti nilai tukar riil, tingkat inflasi dan juga pertumbuhan ekonomi yang diukur berdasarkan produk domestik bruto riil. (M Fauzan, 2018)

Perkembangan pasar modal syariah di Indonesia mengalami peningkatan yang pesat terutama setelah pemerintahan melakukan berbagai regulasi di bidang keuangan dan perbankan termasuk pasar modal syariah. Para pelaku di pasar modal syariah telah menyadari bahwa perdagangan efek dapat memberikan return yang cukup baik bagi investor dan sekaligus memberikan kontribusi yang besar bagi perekonomian di Indonesia. ( (M Fauzan, 2018) 
Pada Maret 2020 setelah pandemi Covid-19 masuk ke Indonesia semua sektor mengalami penurunan terutama dalam sektor ekonomi pada pasar modal syariah dan dengan diterapkannya work from home (WFH) dan lock down di beberapa daerah untuk mengurangi penyebaran Covid-19. Namun saham yang berasal dari bidang farmasi ternyata mengalami kenaikan, yaitu pada saham INAF dan KAEF. Dengan kedua saham tersebut mengalami peningkatan. Dikarenakan banyak masyarakat yang mengkonsumsi obatobatan disaat pandemi Covid-19 ini dibandingkan sebelum pandemi ini terjadi. Dan begitupun setelah kabar beredar di masyarakat bahwa ditemukannya vaksin serta obat untuk virus Covid-19 yang membuat harga saham INAF dan KAEF langsung mengalami peningkatan yang lebih tinggi dari sebelumnya. Sampai sampai saham INAF mengalami suspend atau penghentian sementara beberapa hari karena tingginya kenaikan dalam sehari. Dalam hal tersebut terbukti bahwa saham syariah tetap bisa bertahan di tengah ekonomi akibat Covid-19. Hal ini dikarenakan saham syariah memiliki kemampuan transaksi yang baik sehingga tetap stabil dan instrumen syariah yang lebih less volatile. 
Di tengah pandemi Covid-19 di Indonesia, pasar modal syariah mengalami pertumbuhan secara konsisten. Dilihat dari saham-saham syariah yang berkinerja dengan baik, jumlah saham syariah yang tercatat di Bursa Efek Indonesia (BEI) terus bertambah. dari total saham yang tercatat di BEI dengan kapitalisasi pasar saham syariah. Investor syariah juga mengalami pertumbuhan aktivitas transaksi yang lebih baik di masa pandemic covid 19 ini. Dilihat dari sisi pertumbuhan nilai transaksi investor syariah dan pertumbuhan investor syariah yang secara aktif. Beberapa indikator yang menunjukkan saham syariah mempunyai ketahanan yang kuat terhadap efek yang muncul akibat pandemi Covid-19.

\section{KESIMPULAN}

Keadaan darurat terjadi saat ini akibat adanya COVID 19 yang hampir mempengaruhi seluruh kegiatan masyarakat terutama dalam bidang ekonomi. Pandemi saat ini tidak hanya terjadi masalah di sektor riil saja, namun berimbas juga pada sektor keuangan sehingga perekonomian di Indonesia mengalami penurunan. Perlambatan ekonomi pasti akan berdampak pada pertumbuhan pasar modal syariah. Perkembangan pasar modal 
syariah ini di Indonesia mengalami peningkatan terutama setelah pemerintahan melakukan berbagai regulasi di bidang keuangan termasuk pasar modal syariah. Hal ini dikarenakan saham syariah mempunyai kemampuan transaksi yang baik sehingga tetap stabil dan instrumen syariah yang lebih less volatile.

\section{DAFTAR PUSTAKA}

Abdalloh, I. (2019). Pasar Modal Syariah. Jakarta: Elex Media Komputindo.

Abdi, M. N. (2020). Krisis Ekonomi Global dari Dampak Penyebaran Virus Corona (Covid-19). Jurnal IImiah, 17(1), 90 - 98.

Fathoni, H. (2021). PERAN PASAR MODAL SYARIAH DALAM LAJU PERTUMBUHAN EKONOMI DI INDONESIA. Jurnal Ekoonomi dan Bisnis, 2(1), 33- 44.

Hasya Mazaya Lathifah, D. S. (2021). Dampak Pandemi Covid-19 Terhadap Nilai Harga Saham Syariah di Indonesia. Jurnal IImiah Ekonomi Syariah, 7(1), 1 - 6.

I Irawan, Z. A. (2019). Pengaruh Saham Syariah, Sukuk dan Reksadana Syariah Terhadap Pertumbuhan Ekonomi Indonesia (Tahun 2012 - Tahun 2017). Jurnal Manajemen dan Bisnis Islam, 2(1), 95 - 123.

Khalisah, N. (2014). PASAR MODAL SYARIAH (KETIKA "SYARIAH" 
HANYA SEBUAH KATA). Jurnal Ekonomi, Manajemen, dan Akuntansi Islam, 2(1), 29 - 34.

M Fauzan, D. S. (2018). Peran Pasar Modal Syariah Dalam Mendorong Laju Pertumbuhan Ekonomi Di Indonesia. Jurnal Ekonomi dan Bisnis Islam, 5(1), 70 - 95.

Novitasari. (2020). Perbandingan Pertumbuhan Saham Syariah. Jurnsl Ekonomi Syariah, 1(2), 50 - 64.

Soemitra, A. (2014). Masa Depan Pasar Modal Syariah di Indonesia. Jakarta: Kencana. 